\title{
Conservation tillage systems for cotton advance in the San Joaquin Valley
}

\author{
by Jeffrey P. Mitchell, Lyle Carter, Dan Munk, \\ Karen Klonsky, Robert Hutmacher, Anil \\ Shrestha, Rich DeMoura and Jon Wroble
}

Cotton production in the San Joaquin Valley has traditionally relied heavily on tillage for its presumed benefits to plant establishment, yields and insect management. Research in the $1960 \mathrm{~s}$ and 1970s demonstrated the potential of precision or zone tillage, which foreshadowed the introduction of a variety of minimum tillage implements in the early 1990s. During a 3-year comparison study from 2001 to 2003, cotton yields in strip tillage plots matched or exceeded yields of standard tillage plots in all 3 years. In a 12-year study from 1999 to 2011 , tillage costs were lowered an average of $\$ 70$ per acre in 2011 dollars using no-tillage compared to standard tillage while achieving statistically comparable yields, provided that adequate crop stands were achieved. If bottom-line profitability can be maintained, conservation tillage may become increasingly attractive to cotton producers in the San Joaquin Valley.

Cions otton production systems in the San Joaquin Valley have evolved over the past 60 years to rely heavily on intensive tillage, which is costly. Numerous tillage passes require not only considerable labor and time, but also specialized implements and the tractor power to pull them. Historically, tillage costs have not been a major part of crop production budgets (Hutmacher et al. 2003), but because of rising diesel fuel and equipment costs, they are becoming an increasingly important component of a farm's business model. During the past decade researchers have evaluated a variety of conservation tillage (CT) approaches that reduce the frequency of tillage, and cotton producers are now using some of these approaches.

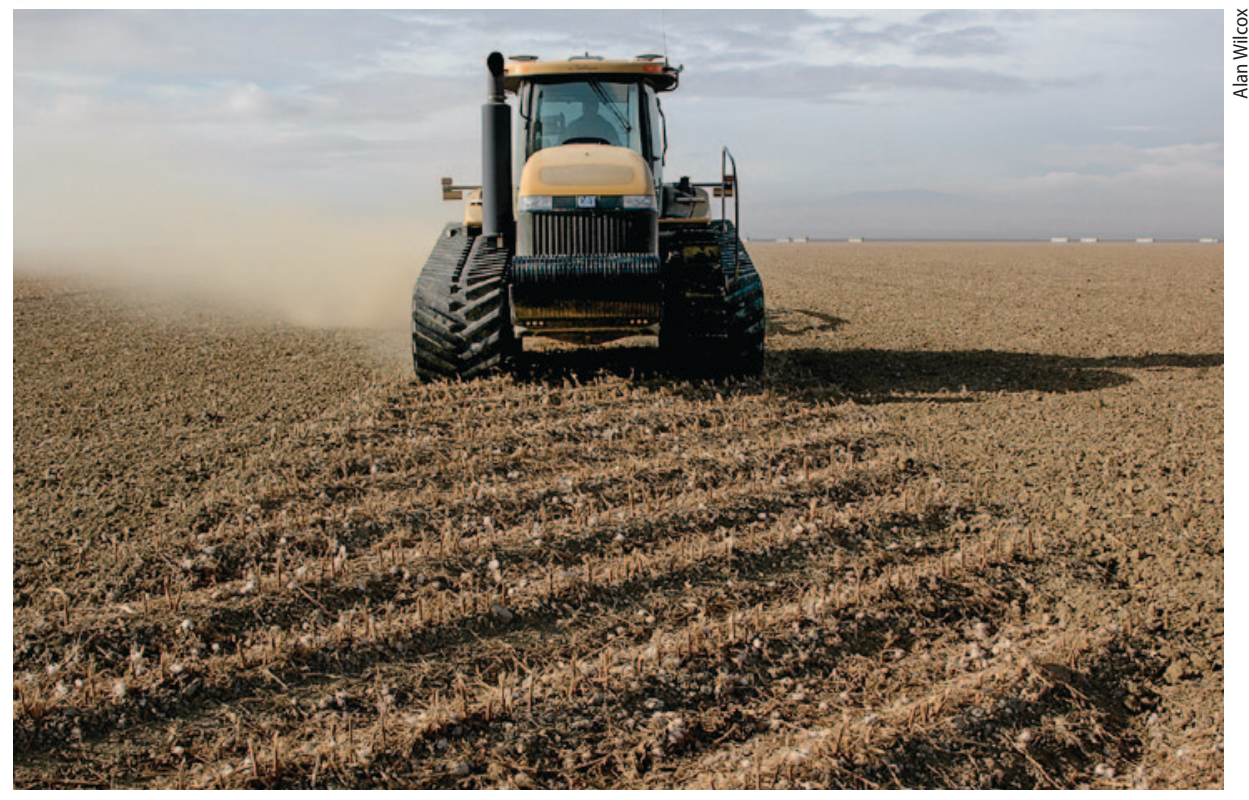

In traditional cotton tillage, fields may undergo multiple operations. New implements and strategies allow growers to significantly reduce that number. A Wilcox Agriproducts Eliminator creates a flat seedbed in one pass after cotton harvest and shredding in Firebaugh, 2006.

\section{Traditional multipass tillage}

Cotton has been an important crop in the San Joaquin Valley for more than 150 years. Tillage management systems for cotton changed relatively little here during the last half of the 20th century (Abernathy et al. 1975; Carter 1996; Carter et al. 1965), and cotton remains a tillageintensive agronomic crop (Mitchell et al. 2007; Mitchell, Pettygrove et al. 2009). Even though there are incentives to reduce tillage, such as the Environmental Quality Incentives Program (EQIP) of the U.S. Department of Agriculture (USDA) Natural Resources Conservation Service (NRCS), most of the crop continues to be produced using traditional, multiple-pass tillage practices (CCTCSW 2011; Mitchell, Pettygrove et al. 2009).

Tillage begins at the end of the previous crop. Aboveground crop material is typically shredded, and roots are undercut and mixed with the soil in a series of diskings designed to provide a host-free period (without cotton plants) in accordance with the California Department of Food and Agriculture's pink bollworm control and eradication program (CDFA 2012), a successful biological control program for insects in operation since the 1960s. In sequence, weeds are then eliminated; herbicides are incorporated; soil clods are broken up; and uniform planting beds are shaped, prepared for furrow irrigation and dry mulched, which is shallow cultivation using rolling harrow implements to kill weeds and even out surface soil moisture. This can amount to six or more field operations before the crop is even seeded (Hutmacher et al. 2003; Mitchell, Pettygrove et al. 2009). In many soil types compaction in subsoil zones is loosened or fractured, annually or less frequently, to avoid root restriction due to consolidated, hard soil layers.

Each tillage pass performs a different function and contributes to reducing the risk of crop failure due to weed pressure, inadequate plant populations and, in some specific cases, damage from insects and pathogens. The sequence of tillage operations is by no means capricious, but in many respects tillage begets tillage: for example, stubble disking requires a carefully devised series of follow-up

Online: http://californiaagriculture.ucanr.edu/ landingpage.. $\mathrm{fm}$ ?article $=$ ca.v066n03p108\&fulltext=yes DOI: $10.3733 /$ ca.v066n03p108 
operations to break up clods created by the disking.

\section{Evolution of minimum tillage}

Minimum tillage is a form of conservation tillage, which by definition reduces the number of tillage passes by $40 \%$ or more compared to conventional practices in 2000 (see glossary) (Mitchell, Pettygrove et al. 2009). Its evolution began in the 1950s.

In 1957 (fig. 1), Al Ruozi in Bakersfield developed a patented one-pass Shredder Bedder (Interstate Equipment \& Mfg., Bakersfield, CA) that could shred aboveground stalks, undercut and kill roots, and then mix cotton residues with soil and prepare new planting beds in one operation. In the 1960s and 1970s, Lyle Carter, USDA Agricultural Research Service engineer at the Cotton Research Center in Shafter, promoted the concept of precision tillage for cotton, in which the only tillage used is in the plant row and not broadcast throughout the entire field (Carter and Stockton 1963; Carter et al. 1965; Stockton et al. 1962). These early efficiency efforts eventually led to the concept of zone production, in which crop growth zones are separated from tractor traffic zones (Carter 1985, 1991; Carter et al. 1987), and in particular to the strip and vertical tillage systems, in which only the crop seed line is tilled. These systems are used to great advantage in the Southeast and increasingly in other regions of the United States, such as Colorado and western Nebraska. In recent years, strip tillage has become more common in San Joaquin Valley dairy corn silage systems, but it is currently not used in cotton.

Carter also developed the spanner, equipment with wide spaces between tractor wheels that covers broad swaths of a field (Carter 1991; Carter et al. 1987). His pioneering systems reduced tractor traffic, energy costs and the soil compaction associated with equipment traffic, which improved soil conditions and water conservation.

More recently, beginning in the mid1990s, implements that combine tillage tools onto a single frame were developed, such as the Optimizer (New World Tillage, Modesto, CA), the Eliminator and Performer (Wilcox Agriproducts, Walnut Grove, CA), the Hahn Bed Disk (Hahn Tractor, Stockton, CA), the Rome-Pegasus

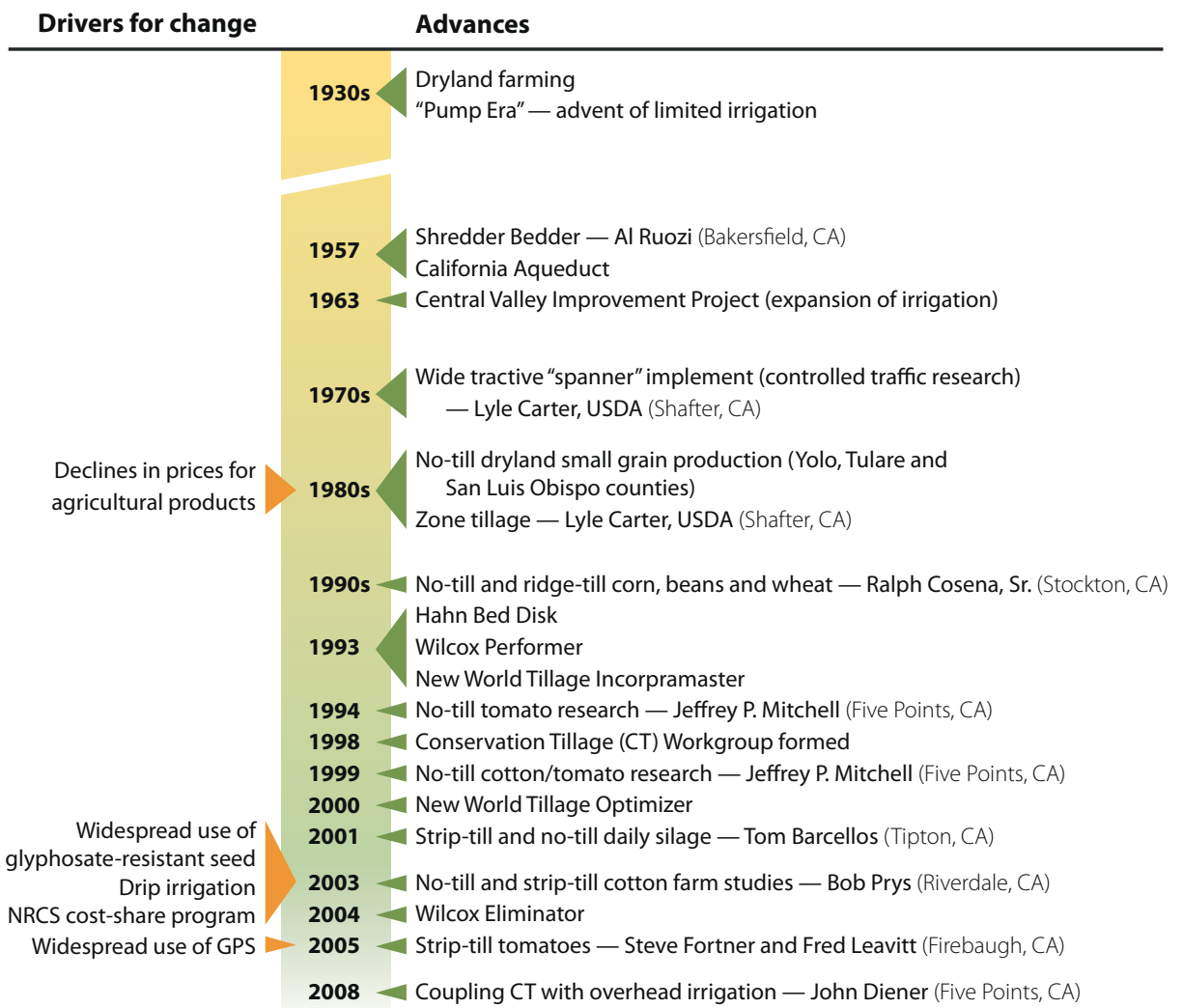

Fig. 1. Changes in tillage management in California's Central Valley.
(Rome Plow Equipment, Cedartown, GA) and the Sundance Wide Bed Disk (Arizona Drip Systems, Coolidge, AZ). This equipment accomplishes tillage functions with fewer passes (Mitchell, Pettygrove et al. 2009). Each of these implements has been successfully used in crop production in some locations and situations; however, most have particular characteristics that can affect where and when they can be best used in fields,

\section{Glossary of tillage systems}

California's Conservation Agriculture Systems Innovation (CASI) initiative has outlined the following general categories of tillage systems. (For more complete definitions and additional information, see Mitchell, Pettygrove et al. 2009.)

Conservation tillage, minimum tillage: Tillage practices that have a conservation goal, such as reducing the volume of soil disturbed and preserving rather than incorporating surface residues, and result in the broad protection of resources. CASI defines conservation tillage as including no-tillage, strip tillage, ridge tillage and mulch tillage systems that preserve $30 \%$ or more of the soil surface covered by residues after planting, and minimum tillage systems that reduce tillage passes by $40 \%$ or more compared with convential practices in 2000.

No-tillage: Seed is planted directly into soil that has been left undisturbed, except for the injection of fertilizers, since harvest of the previous crop.

Ridge tillage: Crops are seeded and grown on ridges or shallow beds formed during the prior growing season, generally during cultivation using implements fitted with sweeps, hilling disks and furrowing wings. Soil is generally left undisturbed from harvest to planting except for fertilizer injection.

Standard tillage: The sequence of operations historically used to prepare a seedbed and produce a crop.

Strip tillage: The seed row is tilled before planting to allow residue removal, soil drying and warming, and in some cases subsoiling. 


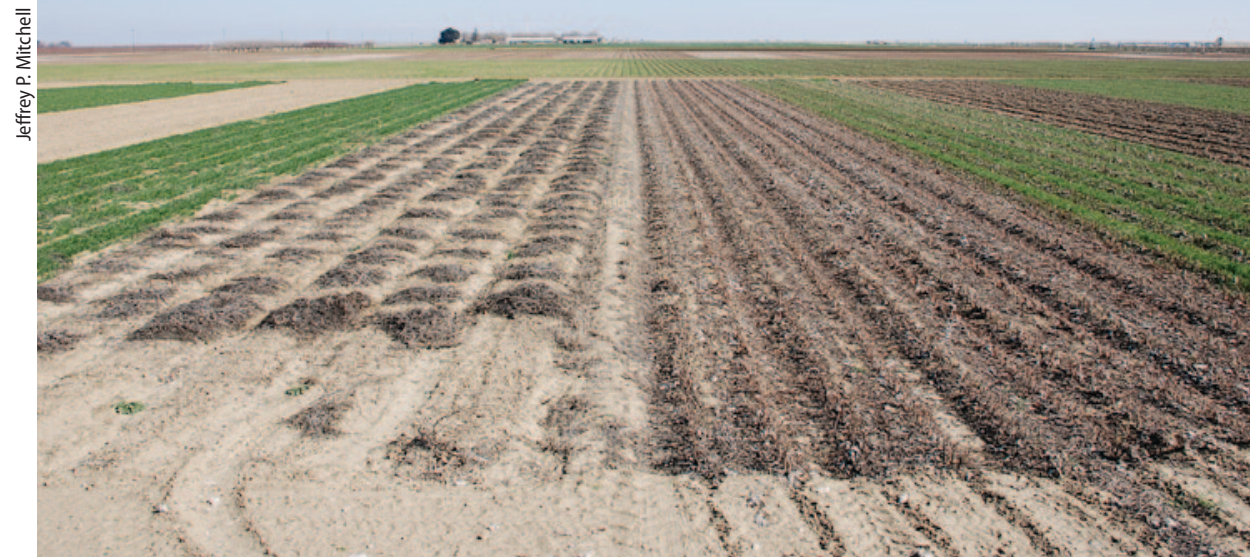

The field layout for the cotton-tomato rotation study shows postharvest tomato beds (left) and conservation tillage cotton beds (right), with and without a cover crop in Five Points, 2007. In later years of the study, cotton lint yields were similar for the conservation tillage and standard systems.

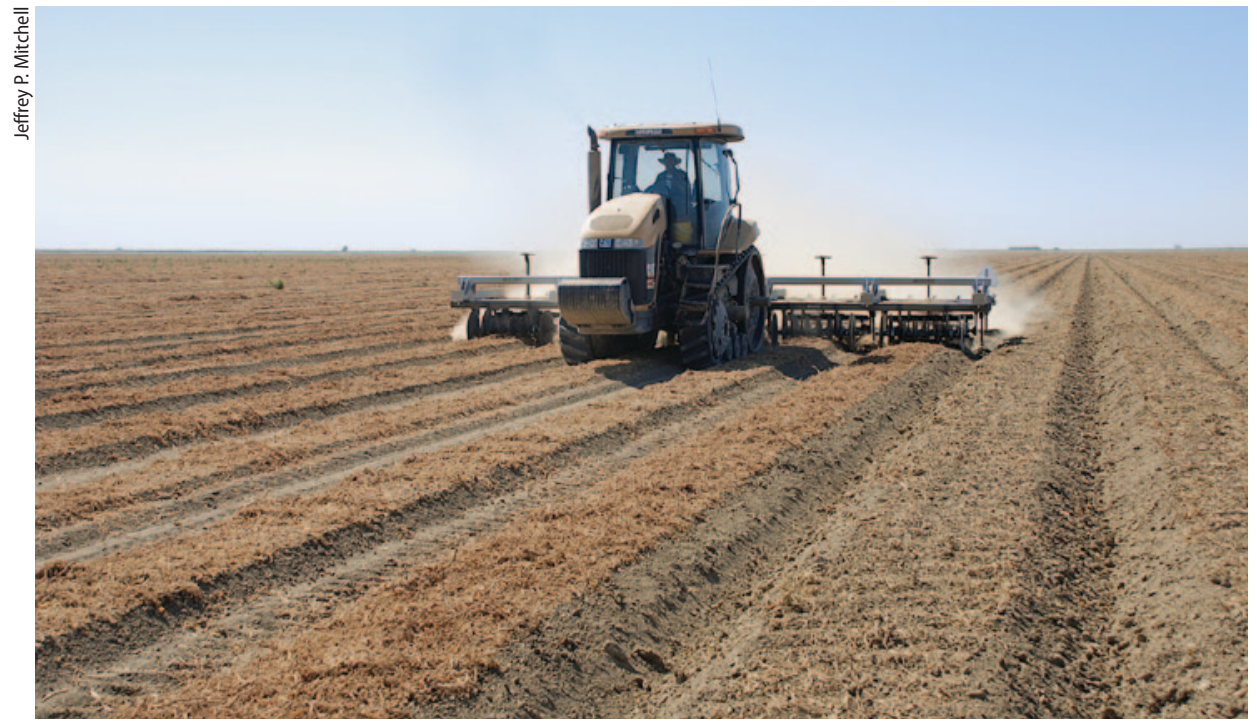

Fewer passes translate into about $\$ 70$ less per acre spent on fuel, labor and repairs. A Wilcox Performer incorporates tomato postharvest residue before the next crop in Five Points, 2007.

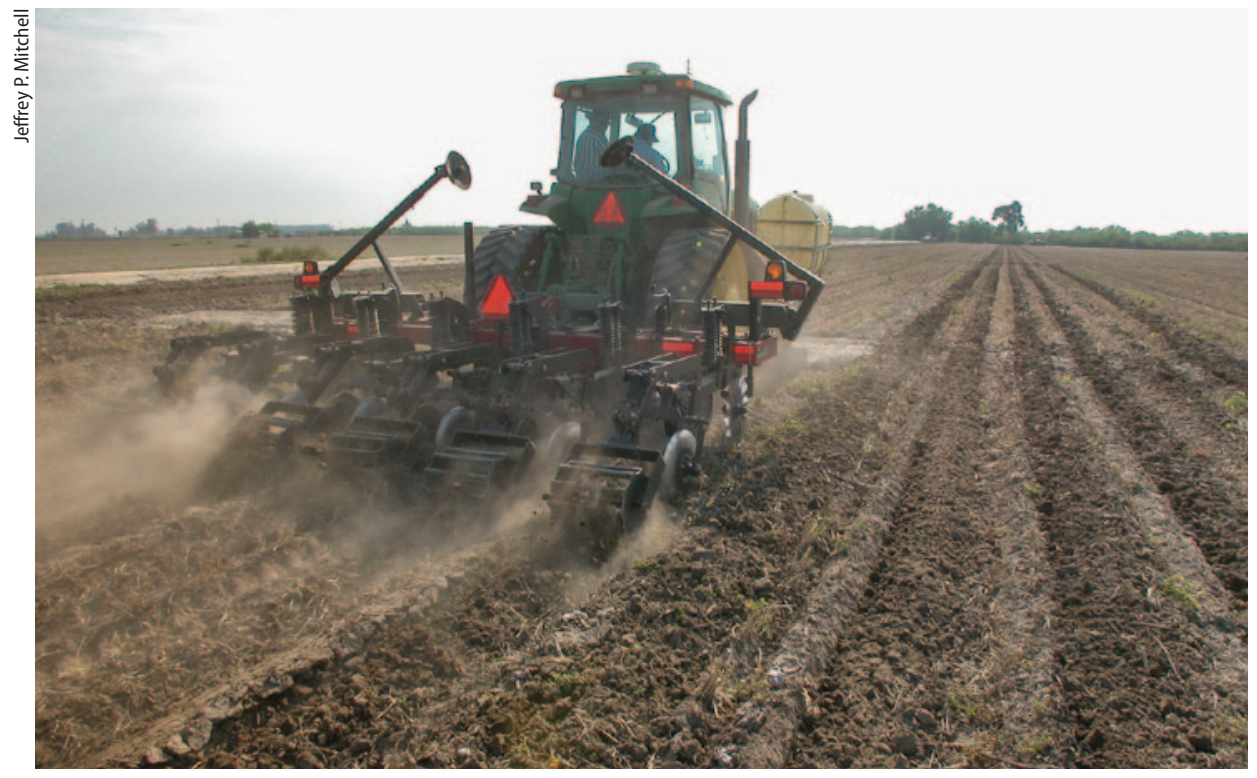

A Case DMI Ecolo-till six-row strip-tiller prepares seedbed strips prior to cotton seeding (in Riverdale, 2003), generating less dust and particulate matter than disking the entire field. depending on factors such as soil texture, moisture content and aggregation. These affect the extent to which the soil fractures and permits good seedbed conditions following operations.

Lowering the number of tillage operations reduces diesel fuel usage (Upadhyaya et al. 2001) and dust generated (Baker et al. 2005; Madden et al. 2008). In the Sacramento Valley, an average savings of $50 \%$ for fuel and $72 \%$ for time have been reported with one-pass tillage equipment (Incorpramaster, New World Tillage, Modesto, CA) compared with the standard tillage program of disking and land planing (Upadhyaya et al. 2001). In a Los Banos cotton field, recent investigations using advanced atmospheric light detection and ranging measurement techniques showed that combined minimum tillage operations (Optimizer) reduced the time and fuel used per acre by $40 \%$ and $50 \%$, respectively, compared with conventional methods. Particulate matter (PM) levels were also reduced $-\mathrm{PM}_{2.5}$ emissions by $29 \%$ and $\mathrm{PM}_{10}$ by $60 \%$ (personal communication, J. Hatfield, Research Leader, USDA ARS National Soil Tilth Lab, Ames, IA).

There are two general types of minimum tillage implements: those that preserve dedicated planting beds and those that do not. In zone tillage - a term originally coined in 1985 to describe the deliberate preservation of crop growth and tractor traffic zones throughout a field permanent or semipermanent bed tillage implements such as the Sundance Wide Bed Disk, Hahn Bed Disk and Wilcox Performer are used with steering guided by global positioning systems (GPS) to maintain beds and traffic furrows (Carter 1985, 1991; Carter et al. 1987). Permanentbed minimum tillage is widely used in subsurface-drip tomato production throughout the San Joaquin Valley's West Side (CCTCSW 2011). Variations of commercially available permanent-bed minimum tillage equipment have been introduced during the last decade. A onepass tillage implement developed in 2001 by Jim Couto, a farmer in Kerman, uses a Bigham Brothers Terratill (Lubbock, TX) strip tillage toolbar fitted with Lilliston rolling cultivators and a roller to recreate beds prior to seeding. The second type of implement is typified by the Eliminator or Optimizer, which do not preserve beds but rather flatten fields while mixing and 
incorporating residues and preparing seedbed tilth in a single pass.

With these minimum tillage implements, less deep or vertical tillage is generally accomplished, while the extent of horizontal or shallow surface tillage is generally similar to conventional tillage. The number of total passes across a field is reduced by combining tillage tools and functions onto one implement. However, unless farmers use techniques that control traffic in the field - restricting tractor and implement load traffic away from crop growth zones - tillage-induced subsoil compaction must still be addressed, and the tillage treadmill may continue even with reduced-pass approaches.

\section{3-year farm tillage study}

The first firm recorded usage of notillage and strip tillage for cotton production in the San Joaquin Valley was in 2000. From 2000 to 2003, Bob Prys, a Riverdale (western Fresno County) farmer, in conjunction with UC researchers, compared various conservation tillage planting and

TABLE 1. Preplant and postharvest tillage operations, Riverdale, 2001-2003

\begin{tabular}{|c|c|c|c|c|c|c|c|}
\hline Tillage operation & $\begin{array}{l}\text { Standard } \\
\text { tillage }\end{array}$ & $\begin{array}{c}\text { No-tillage, } \\
\text { cover } \\
\text { chopped }\end{array}$ & $\begin{array}{c}\text { No-tillage, } \\
\text { no chop }\end{array}$ & $\begin{array}{l}\text { Ridge } \\
\text { tillage, } \\
\text { cover } \\
\text { chopped }\end{array}$ & $\begin{array}{c}\text { Ridge } \\
\text { tillage, } \\
\text { no chop }\end{array}$ & $\begin{array}{l}\text { Strip } \\
\text { tillage, } \\
\text { cover } \\
\text { chopped }\end{array}$ & $\begin{array}{c}\text { Strip } \\
\text { tillage, } \\
\text { no chop }\end{array}$ \\
\hline Spray glyphosate & $\square$ & $\square$ & 口 & $\square$ & 口 & 口 & 口 \\
\hline Chop cover crop & $\mathbf{\square}$ & $\mathbf{\square}$ & & $\mathbf{\square}$ & & $\mathbf{\square}$ & \\
\hline Disk & $\mathbf{\square}$ & & & & & & \\
\hline Disk & $\square$ & & & & & & \\
\hline Chisel & घ & & & & & & \\
\hline Disk & $\square$ & & & & & & \\
\hline List beds & $\mathbf{\square}$ & & & & & & \\
\hline Plant cotton & $\mathbf{\square}$ & $\mathbf{\square}$ & $\mathbf{\square}$ & $\mathbf{\square}$ & $\mathbf{\square}$ & $\mathbf{\square}$ & $\mathbf{\square}$ \\
\hline Ring-roll & $\square$ & & & & & & \\
\hline Apply glyphosate & $\mathbf{\square}$ & $\mathbf{\square}$ & $\mathbf{\square}$ & $\mathbf{\square}$ & $\mathbf{\square}$ & $\square$ & $\mathbf{\square}$ \\
\hline Cultivate & $\mathbf{\square}$ & $\mathbf{\square}$ & $\mathbf{\square}$ & $\mathbf{\square}$ & $\mathbf{\square}$ & $\mathbf{\square}$ & $\mathbf{\square}$ \\
\hline Harvest cotton & $\mathbf{\square}$ & $\mathbf{\square}$ & $\mathbf{\square}$ & $\mathbf{\square}$ & $\mathbf{\square}$ & $\mathbf{\square}$ & $\mathbf{\square}$ \\
\hline Shred stalks & $\mathbf{\square}$ & $\mathbf{\square}$ & $\mathbf{\square}$ & $\mathbf{\square}$ & $\mathbf{\square}$ & $\mathbf{\square}$ & $\mathbf{\square}$ \\
\hline Disk & $\square$ & & & & & & \\
\hline Disk & $\mathbf{\square}$ & & & & & & \\
\hline Subsoil/relist beds & $\mathbf{\square}$ & & & & & & \\
\hline $\begin{array}{l}\text { Root-pull stalks and/or } \\
\text { relist beds }\end{array}$ & & $\mathbf{\square}$ & $\mathbf{\square}$ & $\mathbf{\square}$ & $\mathbf{\square}$ & $\mathbf{\square}$ & $\mathbf{\square}$ \\
\hline Times over field & 16 & 8 & 7 & 8 & 7 & 8 & 7 \\
\hline
\end{tabular}

TABLE 2. Cotton yields, fuel use and operating costs for tillage systems, Riverdale, 2001-2003

\begin{tabular}{|c|c|c|c|c|c|c|}
\hline \multirow[b]{2}{*}{ Tillage system } & \multirow{2}{*}{$\begin{array}{c}\text { Times } \\
\text { over field* }\end{array}$} & \multicolumn{3}{|c|}{ Yield } & \multirow{2}{*}{$\begin{array}{l}\text { Fuel } \\
\text { use }\end{array}$} & \multirow{2}{*}{$\begin{array}{c}\text { Total operating } \\
\text { costs* }^{*}\end{array}$} \\
\hline & & 2001 & 2002 & 2003 & & \\
\hline & & \multicolumn{3}{|c|}{.......... Ibs. lint/acre $\ldots \ldots \ldots \ldots$} & gal./acre & $\$ / a c r e$ \\
\hline Standard tillage & 16 & $993 c t$ & 1,311a & $1,156 n s \neq$ & 19.5 & 237 \\
\hline $\begin{array}{l}\text { No-tillage, cover crop } \\
\text { chopped }\end{array}$ & 8 & $1,183 a b c$ & $1,258 a$ & $1,291 \mathrm{~ns}$ & 7.5 & 199 \\
\hline No-tillage, no chop & 7 & $1,081 b c$ & $1,215 a$ & $1,258 \mathrm{~ns}$ & 7.5 & 195 \\
\hline $\begin{array}{l}\text { Ridge tillage, cover crop } \\
\text { chopped }\end{array}$ & 8 & $1,292 a b c$ & $709 \mathrm{~b}$ & $1,303 \mathrm{~ns}$ & 7.5 & 199 \\
\hline Ridge tillage, no chop & 7 & $1,229 a b c$ & $809 b$ & $1,156 \mathrm{~ns}$ & 7.5 & 195 \\
\hline $\begin{array}{l}\text { Strip tillage, cover crop } \\
\text { chopped }\end{array}$ & 8 & $1,352 a$ & $1,278 a$ & $1,365 \mathrm{~ns}$ & 10.2 & 204 \\
\hline Strip tillage, no chop & 7 & $1,262 a b$ & $1,223 a$ & 1,340 ns & 9.2 & 200 \\
\hline
\end{tabular}

stalk management systems with standard tillage practices in three successive cotton crops (Mitchell et al. 2006). In this study, three replications of seven cotton planting and postharvest stalk management systems were set out with 30 -inch spacing between rows across a 12-acre field of Panoche clay loam soil. Before each cotton crop, a winter cover crop of barley (Hordeum vulgare) was grown across the entire experimental field to add organic matter to the soil and improve tilth. The cover crop was terminated by spraying glyphosate or by a combination of glyphosate and mowing. Sixteen trips across the field were made in the standard tillage plot, whereas seven or eight were made in the alternative system plots (table 1).

Yield and details on each of these cotton tillage systems for the first 2 years of this study have been previously reported (Mitchell et al. 2006). An important finding was that strip tillage resulted in yields that for 2 years consistently matched and in 1 year exceeded those of the control (table 2). The study also showed that conservation tillage produced higher yields over the 3-year study, and reductions in operating costs from eliminating tillage passes were about $\$ 40$ per acre.

\section{2-year UC tillage study}

To determine the longer-term impacts of conservation tillage on productivity, profitability and soil properties, a study has been under way since 1999 at the UC

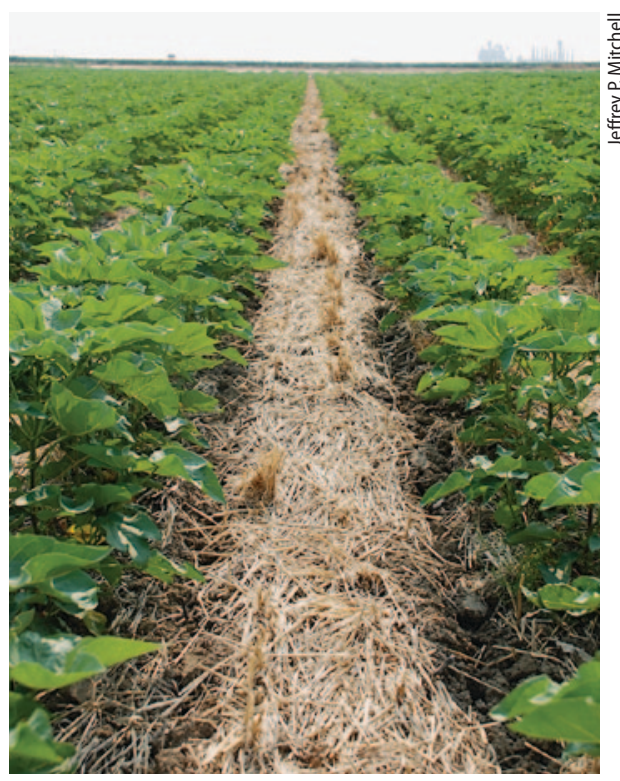

Glyphosate-resistant Acala cotton was grown in a winter triticale, rye and pea cover crop with no tillage in Five Points, 2007. 
West Side Research and Extension Center in Five Points. The study is comparing standard and conservation tillage systems for a cotton-tomato rotation, with and without a mixture of cover crops in a deep, relatively uniform clay loam soil. The cover crops are rainfed winter triticale (Triticosecale Wittm.), Merced ryegrain (Secale cereale L.) and common vetch (Vicia sativa). In the conservation tillage plots, cotton has been seeded directly each year into tomato beds that are not disturbed following harvest. All tractor and implement traffic is restricted to the furrows, and planting beds are not moved or tilled, except for shallow weed cultivations during each tomato season using a modified Sukup high-residue cultivator (Sheffield, IA). The number of tractor trips across the field was reduced by about $50 \%$ for tomato and $40 \%$ for cotton in the conservation tillage plots (table 3 ). Additional glyphosate herbicide sprays were required to kill the cover crops.

'Riata', a glyphosate-resistant (Roundup Ready) transgenic Acala cotton variety (Bayer Crop Science, Shafter, CA), was used until 2008 and 2009, when 'Phy 8212 RF', an experimental Roundup Ready Flex Pima variety (Phytogen/Dow, Corcoran, CA), was grown to evaluate these tillage systems for Pima cotton. The Acala variety 'Phy 725 RF' (Phytogen/ Dow) was used in 2010 and 2011.

Yields. Yields of Acala cotton in the conservation tillage systems were generally lower than in the standard systems from 2001 through 2004 but similar to those in the standard systems from 2005 through 2007, 2010 and 2011 (fig. 2). Yields of the Pima variety were lower in 2008 and 2009 than Acala yields in other years. Pima has a relatively aggressive,
TABLE 3. Comparison of standard and conservation tillage operations in cotton with and without a cover crop, Five Points, 2000-2011

\begin{tabular}{|c|c|c|c|c|}
\hline \multirow[b]{2}{*}{ Tillage operation } & \multicolumn{2}{|c|}{ With cover crop } & \multicolumn{2}{|c|}{ Without cover crop } \\
\hline & Standard & Conservation & Standard & Conservation \\
\hline Disk & $\mathbf{\square} \mathbf{a}^{*}$ & & 口ם & \\
\hline Chisel & $\square$ & & $\mathbf{\square}$ & \\
\hline \multicolumn{5}{|l|}{ Level (triplane) } \\
\hline List beds & $\square$ & & 무 & \\
\hline Spray herbicide (triflularin) & $\mathbf{\square}$ & & $\mathbf{\square}$ & \\
\hline Incorporate herbicide & $\square$ & & $\square \square$ & \\
\hline Spray herbicide (glyphosate) & $\mathbf{\square}$ & 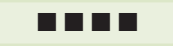 & $\square$ & $\square \square \square$ \\
\hline Cultivate & $\square \square$ & & $\square$ & \\
\hline Chain beds & $\square$ & $\square$ & & \\
\hline Plant cotton & $\mathbf{\square}$ & $\square$ & $\mathbf{\square}$ & $\square$ \\
\hline Fertilize & $\square$ & $\square$ & $\square$ & $\square$ \\
\hline Plant cover crop & $\square$ & $\square$ & & \\
\hline Mow cover crop & $\mathbf{\square}$ & $\square$ & & \\
\hline Spray insecticides/growth regulators & $\square$ & $\square \square$ & $\square$ & $\square \square$ \\
\hline Spray defoliant & $\mathbf{\square}$ & $\mathbf{\square}$ & $\mathbf{\square}$ & $\mathbf{\square}$ \\
\hline Harvest & $\mathbf{\square}$ & $\square$ & $\square$ & $\square$ \\
\hline Times over field & 20 & 13 & 16 & 9 \\
\hline
\end{tabular}

indeterminate growth habit, which can be more difficult to manage for high yields unless the right combination of plant growth regulator and deficit irrigation management is used, and this seemed to affect the Pima yields.

Cost comparison. The number of tractor passes in the standard and conservation tillage plots without a cover crop was 16 and 9, respectively (table 3). This resulted in a fuel reduction of 12 gallons and 2 fewer labor hours per acre in the conservation tillage plots compared to the standard plots. The savings in fuel, labor and repairs amounted to approximately $\$ 70$ per acre in 2011 dollars. The cover crop added four operations for the standard and conservation tillage treatments

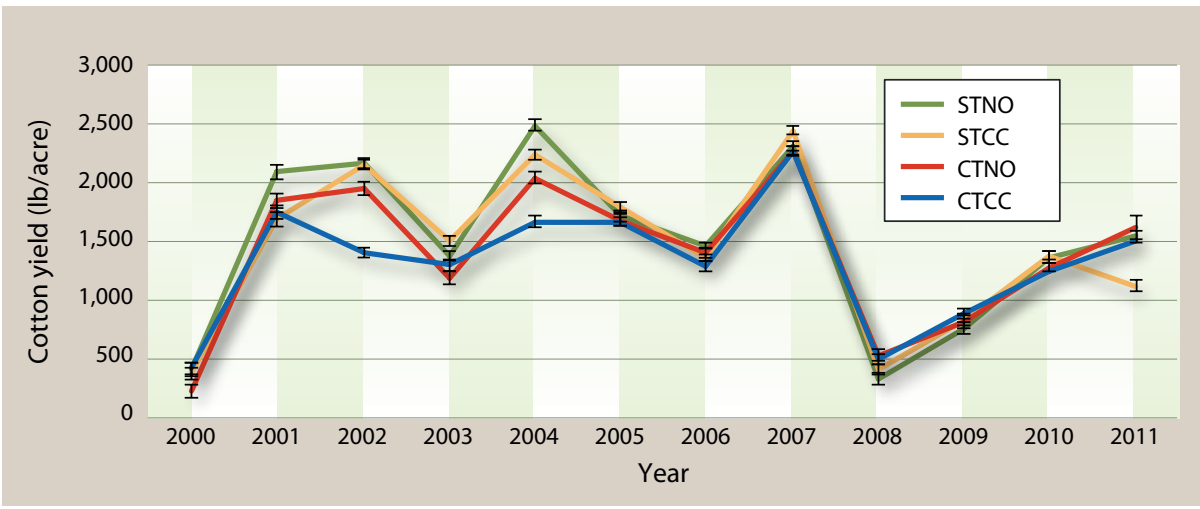

Fig. 2. Lint cotton yields in comparison study of conservation (CT) and standard (ST) tillage systems, with (CC) and without (NO) cover crops at UC West Side Research and Extension Center, 2000-2011. and resulted in an increase of about $\$ 50$ per acre compared to plots with no cover crops. Consequently, the highest-cost system was standard tillage with a cover crop, followed by standard tillage without a cover crop. The two conservation tillage systems had the lowest costs. All systems were profitable in all years except the first year of the study, when yields were much lower due to a mite infestation from a neighboring field.

Early seeding. Yield increases in the conservation tillage plots after the first 4 years were due to more successful planting operations. In the 4 th year, cotton seed was planted early into moist soil, which resulted in better early-season seedling vigor and higher plant populations and yields. Capping or pulling a shallow layer of dry soil directly over the seed line at planting - to preserve seed zone moisture during germination and early seedling growth - and then removing it when the seedlings are about to emerge, is standard practice in the western San Joaquin Valley. Because no soil cap is pulled over the seed line with conservation tillage, the timing of seeding is critical; seedlings need to rapidly develop a tap root that extends into deeper soil moisture before the surface soil dries out by evaporation, so seeding must take place when there is adequate soil moisture and good weather for seedling development and emergence. 
TABLE 4. Tillage and cover crop system impacts on soil quality and diesel fuel use, Five Points, 2007-2008

\begin{tabular}{|c|c|c|c|c|}
\hline Cropping system & $\begin{array}{l}\text { Soil conditioning } \\
\text { index }(\mathrm{SCl}) \text { values }\end{array}$ & $\begin{array}{c}\text { Soil tillage } \\
\text { intensity rating } \\
(\mathrm{STIR})^{*}\end{array}$ & $\begin{array}{c}\text { Diesel fuel } \\
\text { use }\end{array}$ & $\begin{array}{l}\text { Fuel cost for cotton- } \\
\text { tomato rotation }\end{array}$ \\
\hline & & & gal./acre & \$/acre \\
\hline Standard tillage, no cover crop & -0.71 & 261.0 & 32.0 & 128.6 \\
\hline Standard tillage, cover crop & -0.96 & 390.0 & 40.0 & 160.6 \\
\hline Conservation tillage, no cover crop & 0.43 & 30.6 & 9.3 & 36.8 \\
\hline Conservation tillage, cover crop & 0.52 & 37.1 & 11.0 & 43.3 \\
\hline
\end{tabular}

As a result, seeding early into moist soil is a critical requirement of no-tillage cotton production in the San Joaquin Valley.

\section{Soil improvements}

The long-term nature of this UC tillage comparison is unique in California, and it has provided opportunities to evaluate the impacts of tillage and cover cropping on soil attributes and fuel use (table 4). The Soil Conditioning Index (SCI) has been proposed by researchers with the USDA NRCS (2003) as a predictor of the consequences of management on soil organic carbon or more specifically on par-
The Soil Tillage Intensity Rating (STIR) assesses the impact of tillage operations on soil quality and residue retention, which is important in reducing soil erosion and water evaporation (USDA NRCS 2003). It is calculated from the operational speed of tillage equipment, the particular type of tillage used, the depth of tillage and the percentage of soil surface area disturbed. It also is used as a scoring index for participation in Farm Bill conservation programs and cost-share eligibility.

No-tillage by definition requires a STIR value of 30 or less. Values in the USDA's national database typically range from 0

\section{The UC studies have consistently shown that conservation tillage can yield as well as standard tillage in a cotton-tomato rotation.}

ticulate organic matter, which is a labile precursor of more stable forms of soil carbon. NRCS uses the SCI as one criterion for determining eligibility for Farm Bill conservation programs such as EQIP. In our study, the computed SCI values were negative for the two standard systems and positive for conservation tillage (table 4). Positive SCI values generally indicate that soil carbon - which is considered a keystone element or component of soil quality because of its role in increasing water- and nutrient-holding capacities is increasing, while negative values suggest degrading trends (USDA NRCS 2003; Zobeck et al. 2007). Zobeck et al. (2007) suggested using a buffer of plus or minus 0.2 to 0.3 when reporting SCI values to account for variation associated with SCI estimates. The differences in SCI between standard and conservation tillage systems in our work were greater than these buffered SCI values, indicating significant differences in soil resource quality, a key determinant of crop productivity.

\section{Ultra-narrow row tillage}

Ultra-narrow drill seeding of cotton into 60-inch tomato beds was evaluated through three cycles of a tomato-cotton rotation as part of the long-term study of conservation tillage at UC West Side Research and Extension Center. A 15-foot John Deere 1560 no-tillage drill with 7.5-inch between-row spacing was used to establish the ultra-narrow row system. Very high plant populations, exceeding 80,000 per acre (compared with the 48,000 to 60,000 typical of commercial cotton fields) have been achieved with this method. Compared to standard tillage, no-tillage, strip tillage and twin-row no-tillage plots in the same study, ultranarrow rows resulted in cheaper crop establishment. In addition, raw yields were comparable to the highest-yielding system in each year. However, its gin turnout percentages were generally lower than other systems, and final yields were lower (table 5). It also required stripperhead harvesters, which are currently not widely available in the San Joaquin Valley.

As in the 12-year study, the yields with conservation tillage improved with time. By year 2 of the study, the yields of the no-tillage and strip tillage plots did not differ significantly from those of standard tillage; and in year 3 there were no significant differences between yields in any of the systems.

to 200 , with a low score preferred. We believe that the STIR values in table 4 are the first published numbers for cotton tillage systems in the San Joaquin Valley using this assessment tool. Values are high for the standard systems, particularly those with a cover crop. These systems presumably would not qualify for cost-share support under conservation programs aimed at residue retention or soil quality preservation.

\section{Yields versus profits}

The UC studies have consistently shown that conservation tillage can yield as well as standard tillage in a cottontomato rotation. This finding agrees with a broad comparison of cotton tillage systems across seven states at 12 Monsanto Centers of Excellence sites from 1998 through 2002 (Buman et al. 2005). In the Monsanto work, differences in lint yield
TABLE 5. Cotton lint yields in three-rotation cotton-tomato tillage study, with cotton seeded after tomato harvest, Five Points, 2003-2007

\begin{tabular}{|c|c|c|c|}
\hline Tillage system & 2003 & 2005 & 2007 \\
\hline & ….. & Ibs./acre & …… \\
\hline Standard tillage & $1,638 a^{*}$ & $1,475 a$ & 1,885nst \\
\hline No-tillage & $1,538 b$ & $1,464 a$ & $1,929 \mathrm{~ns}$ \\
\hline Strip tillage & $1,348 c$ & $1,450 a$ & $1,887 \mathrm{~ns}$ \\
\hline Twin row, no-tillage & 1,696a & $1,371 b$ & $1,893 \mathrm{~ns}$ \\
\hline Ultra-narrow row, no-tillage & $1,540 \mathrm{~b}$ & $1,280 \mathrm{~b}$ & $1,821 \mathrm{~ns}$ \\
\hline
\end{tabular}




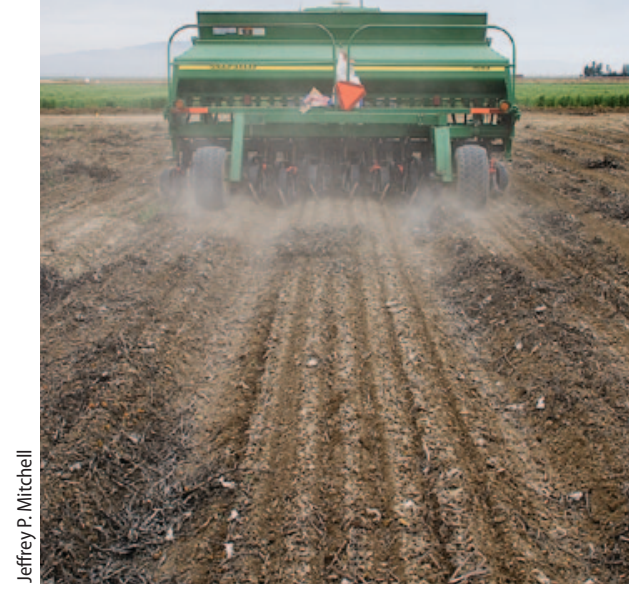

A John Deere 1560 15-foot no-tillage drill is used to seed cotton in ultra-narrow rows at 7.5-inch spacing in Five Points, 2007.

between no-tillage, strip tillage, reduced tillage and conventional tillage systems were not significant. The 5-year average profit for the no-tillage system ranged from $\$ 7$ to $\$ 66$ per acre higher than for the other three systems. This work concluded that farmers and crop consultants should consider overall profit rather than just crop yield when evaluating alternative tillage practices.

\section{Pink bollworm and tillage}

Effective control of pink bollworm (Pectinophora gossypiella), a pest that damages cotton bolls and has cost the U.S. cotton industry billions of dollars, has been a long-standing priority of San Joaquin Valley cotton producers. The California pink bollworm control and eradication program (CDFA 2012) has been highly successful, but it requires intensive tillage, including the postharvest shredding of cotton stalks, some form of root undercutting or dislodging, and the mixing of residues with surface soil to guarantee that no living cotton plants remain in a field during the host-free period (mid- to late December through March 10). This sequence of tillage operations typically results in clean, residue-free fields following cotton harvest.

We are evaluating a variety of postharvest management options that can effectively manage pink bollworm and reduce soil disturbance in Five Points, in conjunction with the CDFA control and eradication program. Various root-puller or root-cutting implements may comply with mandated regulations and reduce overall tillage. One such implement is a root cutter designed by J. Diener, a Five Points farmer. It has rotating horizontal disk blades that are shallowly pulled through the soil, shearing off and dislodging cotton roots and stalks with less overall soil disturbance than typical conventional stubble-disking. A root puller made by Arizona Drip Systems (Coolidge, AZ) has angled disk blades that uproot and dislodge roots as it is drawn through the field. During the 8-acre, 12-year comparison study, no pink bollworm finds were recorded in traps monitored by the CDFA program.

\section{Other crop rotations}

Preceding or following cotton with crops such as wheat or triticale may work well in conservation tillage systems, provided that care is given to seeding operations to ensure adequate stands (table 6). In research studies, uniform stands of

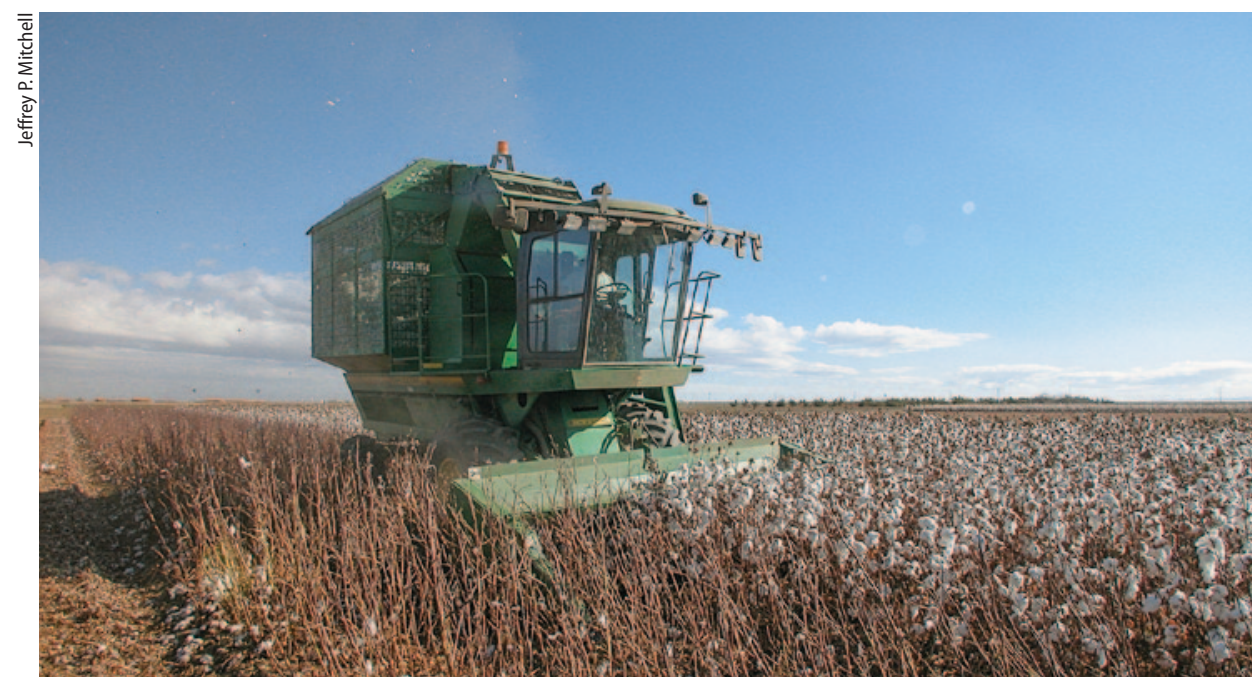

A stripper harvester is used to pick cotton in ultra-narrow rows in Five Points, 2007. 


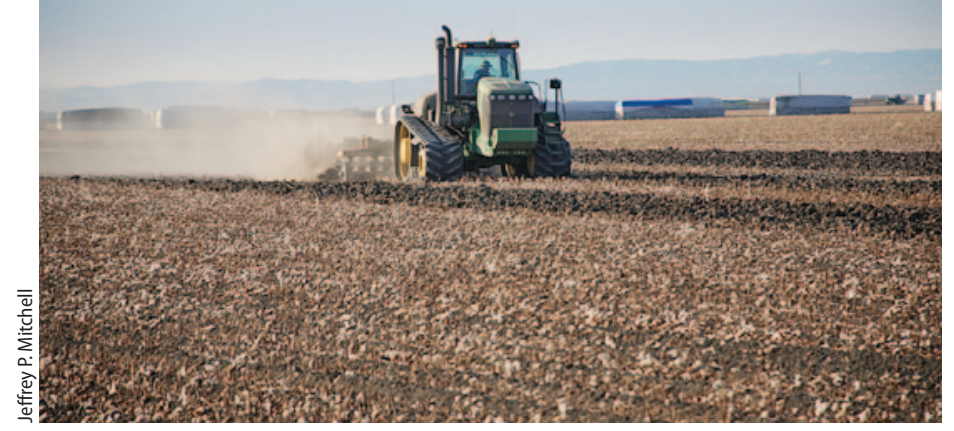

Standard postharvest cotton tillage includes shredding aboveground cotton plants and disking the residues as carried out in Firebaugh, 2007.

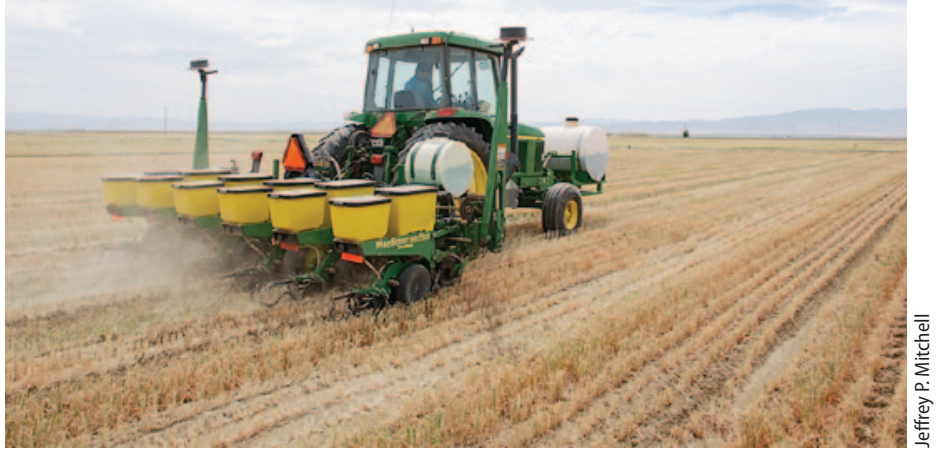

With conservation tillage a crop is seeded directly into wheat stubble, shown in Five Points, 2009. refinement of conservation tillage systems in California. A wide range of innovative equipment has been introduced to the region, which has functioned successfully under various conditions. Whether conservation tillage has a larger future depends on two critical factors: the need to achieve vigorous crop stands and the need to avoid soil compaction.

Inadequate plant populations and low seedling vigor have been the greatest problems associated with reduced yields in conservation tillage cotton in California to date. With no cap of dry soil pulled over the seed line at planting to preserve moisture in the seed zone, the risk of uneven emergence and weakened seedlings is great unless care is taken to avoid these problems. Further innovation in equipment modification could improve the soil cover of seeded crops. Currently, a relatively narrow range of soil moisture, temperature, aeration and impedance conditions must all be present for successful crop stands. The challenge is greater in flat fields than in fields with prepared beds because there is less opportunity to

\section{References}

Abernathy GH, Cannon MD, Carter LM, Chancellor WJ. 1975. Tillage Systems for Cotton - A Comparison in the U.S. Western Region. California Agricultural Experiment Station Bulletin 870.

Baker JB, Southard RJ, Mitchell JP. 2005. Agricultural dust production and composition in standard and conservation tillage systems in the San Joaquin Valley. J Envir Qual 34:1260-9.

Bradley JF. 1995. Success with no-till cotton. In: Conservation Tillage Systems for Cotton: A Review of Research and Demonstration Results from across the Cotton Belt. Arkansas Agricultural Experiment Station Special Report 169. Jackson, MS. p 31-5.

Buman RA, Alessi BA, Bradley JF, et al. 2005. Profit and yield of tillage in cotton production systems. J Soil Water Conserv 60(5):235-42.

Carter LM. 1985. Wheel traffic is costly. T ASAE 28(2):430-4. Carter LM. 1991. Zone production system for cotton: Soil response. TASAE 34(2):354-60.

Carter LM. 1996. Tillage. In: Cotton Production Manual. UC ANR Pub 3352. Oakland, CA. p 175-86. push away surface soil during the planting operation in order to reach stored soil moisture without creating ruts or gullies along the seed line.

To date, no rigorous determinations of subsurface compaction arising from tractor and implement traffic have been conducted in the San Joaquin Valley. The bulk of the work reported here has been of short duration, has used minimum tillage equipment that successfully alleviates compaction, or has relied on dedicated traffic and crop growth zones, which minimize compaction risks. To be sustainable over the long term, conservation tillage will likely need to use a combination of deliberate techniques to avoid compaction with zone or vertical tillage (Carter 1996). Because California cotton is grown in a broad range of soil types, more research is needed on the relationship between soil compaction and type, moisture content, load weight and repetition of tillage operations.

Provided that yield performance or more importantly bottom-line profitability is maintained and the risks associated with adopting a new tillage system are deemed reasonable, conservation tillage systems may become increasingly attractive to producers and more common in San Joaquin Valley cotton-growing areas.

J.P. Mitchell is Cropping Systems Specialist, Department of Plant Sciences, UC Davis; L. Carter is Retired Engineer, U.S. Department of Agriculture Agricultural Research Service, Shafter Cotton Research Station; D. Munk is UC Cooperative Extension Farm Advisor, Fresno County; K. Klonsky is Agricultural Economics Specialist, Department of Agricultural and Resource Economics, UC Davis; R. Hutmacher is Cotton Specialist and Director, UC West Side Research and Extension Center, Five Points; A. Shrestha is Associate Professor of Weed Science, California State University, Fresno; $R$. DeMoura is Production Cost Analyst, Department of Agricultural and Resource Economics, UC Davis; and J. Wroble is Field Technician, UC Cooperative Extension, Fresno County.

We thank Monte Bottens of California Ag Solutions, Madera, for help and guidance with cotton planting equipment, and the California Tomato Research Institute for their support of the tomato portions of this rotation work.
Carter LM, Rechel EA, Meek BD. 1987. Zone production system concept. In: Orzolek MD (ed.). Controlled Traffic Cropping Systems for Management of Soil Compaction. Acta Horticulturae 210. p 25-34.

Carter LM, Stockton JR. 1963. Minimum tillage possibilities. In: Proc Western Cotton Production Conference, Phoenix, AZ, March 16, 1963. Mesquite, TX: Cotton Gin Oil Mill Pr. p 34.

Carter LM, Stockton JR, Tavernetti JR, Colwick RF. 1965. Precision tillage for cotton production. T ASAE 8(2):177-9. [CCTCSW] California's Conservation Tillage and Cropping Systems Workgroup. 2011. 2010 Tillage Survey. http:// groups.ucanr.org/ucct.

[CDFA] California Department of Food and Agriculture. 2012. Pink Bollworm: Program Details. Sacramento, CA. www.cdfa.ca.gov/phpps/ipc/pinkbollworm/ pbw_hp.htm.

Hutmacher RB, Vargas RN, Weir BL, et al. 2003. Sample Costs to Produce Cotton. UC Cooperative Extension. Davis, CA. http://coststudies/ucdavis.edu.

Madden NM, Southard RJ, Mitchell JP. 2008. Conservation tillage reduced $\mathrm{PM}_{10}$ emissions in dairy forage rotations. Atmos Environ 42:3795-808.
Mitchell JP, Klonsky KM, Miyao EM, Hembree KJ. 2009. Conservation Tillage Tomato Production in California's San Joaquin Valley. UC ANR Pub 8330. Oakland, CA. Mitchell JP, Klonsky K, Shrestha A, et al. 2007. Adoption of conservation tillage in California: Current status and future perspectives. Aust J Exp Agr 47(12):1383-8.

Mitchell JP, Munk DS, Prys B, et al. 2006. Conservation tillage cotton production systems compared in the San Joaquin Valley. Cal Ag 60(3):140-5.

Mitchell JP, Pettygrove G, Upadhyaya S, et al. 2009. Classification of Conservation Tillage Practices in California Irrigated Row Crop Systems. ANR Pub 8364. Oakland, CA. Stockton JR, Carter LM, Bassett DM, Yamada H. 1962. Precision tillage for cotton production. Cal Ag 16(1):10-1. Upadhyaya SK, Lancas KP, Santos-Filho AG, Raghuwanshi NS. 2001. One-pass tillage equipment outstrips conventional tillage method. Cal Ag 55(5):44-7.

[USDA NRCS] US Department of Agriculture Natural Resources Conservation Service. 2003. Interpreting the Soil Conditioning Index: A Tool for Measuring Soil Organic Matter Trends. Tech Note No. 16. Soil Quality Institute. Auburn, AL. 6 p.

Zobeck TM, Crownover J, Dollar M, et al. 2007. Investigation of soil conditioning index values for southern High Plains agroecosystems. J Soil Water Conserv 62(6):433-42. 